\title{
FLORISTIC VARIATION IN COMMUNITIES OF FALLOW LANDS OF THE PODLASKI PRZEEOM BUGU MESOREGION DEPENDING ON THE TIME OF REMOVAL OF FIELDS FROM CULTIVATION
}

\author{
Janina Skrzyczyńska, Piotr Stachowicz, Zofia Rzymowska, Teresa Skrajna \\ Department of Agricultural Ecology, University of Natural Sciences and Humanities \\ ul. Prusa 14, 08-110 Siedlce \\ e-mail: ekorol@uph.edu.pl
}

Received: 15.03 .2013

\begin{abstract}
A study of fallow lands in the Podlaski Przełom Bugu (Podlasie Bug River Gorge) mesoregion was conducted over the period 2001-2004 in 77 villages belonging to 20 municipalities located in the Bug River valley along the stretch of the river from Terespol to Małkinia Górna. The aim of this study was to carry out a survey of vascular plants in fallow lands and to perform their multifaceted analysis. The study investigated quantitative and qualitative changes taking place in fallow vegetation with the passage of time from the abandonment of purposeful cultivation. Plant patches in 1-2-year, 3-6-year, 7-10-year and more than 10-year fallows were studied. Vascular plants of fallow lands within the study area comprise 442 species. 3-6-year fallows were richest in species (355). With increasing fallow age, the number of species decreased to 205 species in fallows older than 10 years. Hemicryptophytes dominated in plant communities of fallow lands. Therophytes were the co-dominant biological type in the youngest fallows. Chamaephytes and geophytes in all fellow age groups accounted for about 5\%. Among vascular plants of fallow lands, native species dominated and their percentage increased with increasing fallow age, while at the same time the proportion of archeophytes decreased. With the increasing age of fallows, the proportion of species characteristic of forest communities also increased, whereas the percentage of segetal species simultaneously decreased. With the passage of time from the abandonment of cultivation, one can observe the evolution of plant cover of fallow fields from segetal communities towards less synanthropic communities.
\end{abstract}

Key words: vascular plants, fallow lands, Podlaski Przełom Bugu, multifaceted analysis

\section{INTRODUCTION}

Agricultural landscape is a result of humaninduced transformations of the natural environment which have been going on for centuries. It is a dominant type of landscape in Poland and in most European countries [1]. Agriculture impacts the natural environment and creates habitats for many organisms, among which some have a positive effect on agroecosystems, while other ones affect them negatively [2].

The increasing intensification of agriculture, which has been observed in recent years, has a negative effect on the biological diversity of agricultural landscape in our country and across Europe [3]. Extensively cultivated agricultural land of high environmental value is disappearing. Intensive farming is used more and more frequently on good quality agricultural land, whereas poorer soils are fallowed or forested. In the municipalities located within the Podlaski Przełom Bugu mesoregion, the estimated area of fallow land is $8.5 \%$ of total agricultural land and it most often results from low production capacity of these soils. Adverse changes take place in fallow fields in which no purposeful agronomic treatments are carried out, among others the following: physical and chemical degradation of the soil, contamination of the soil of fallow land and adjacent fields with weed seeds, expansion of persistent species [4,5]. On the other hand, fallow lands perform important environmental functions: they increase biodiversity, are a refuge for animals and an element of ecological corridors, form a biological buffer, and diversify the agricultural landscape $[4,6,7]$.

The aim of the present study was to carry out a survey of vascular plants in fallow lands in the Podlaski Przełom Bugu mesoregion and to perform their multifaceted analysis. The study also determined quantitative and qualitative changes taking place in vascular plants of fallow lands, depending on the period of time passed from the abandonment of cultivation. 


\section{THE STUDY AREA}

The study area is situated in eastern Poland. According to the physico-geographical division of $\mathrm{K} \mathrm{o} \mathrm{n} \mathrm{-}$ $\mathrm{d} \mathrm{r}$ a c k i [8], it is located in the Podlaski Przełom Bugu (Podlasie Bug River Gorge) mesoregion. The study was conducted in the Bug River valley and it covered an area $155 \mathrm{~km}$ long and $5 \mathrm{~km}$ wide. The investigated area is situated on the north-eastern edge of the former Upper Cretaceous sea and of the Tertiary inundation. Tertiary deposits in the form of sands, silts and clays primarily originate from the terrestrial Miocene $[9,10]$. The present river valley was formed by fluvioglacial waters of the Central Polish glaciation, the Warta stadial. There are well-developed terraces in the river valley: a floodplain terrace and an alluvial terrace. The floodplain terrace formed 1-2 $\mathrm{m}$ above river level and is composed mainly of medium sands overlaid by flood deposits in the form of sandy silts and silty sands. The oxbow lakes that occur there are filled with organic and alluvial sediments. The alluvial terrace is higher and reaches 3-5 $\mathrm{m}$ above river level. Within its boundaries, there are dunes, hummocks and aeolian sand sheets. Moraine plateaus occupy a major part of the study area outside the river valley and they are characterized by diversity of topographic features $[8,9]$.

The investigated area belongs to the PodlasiePolesie climatic region [11]. This region is characterized by a large number of cloudy days without precipitation. The mean annual air temperature is $7-8^{\circ} \mathrm{C}$, whereas the annual total precipitation ranges from 550 to $600 \mathrm{~mm}$. The growing season lasts 205-210 days; it starts on 5, 6 April and ends on 28, 29 October [12].

Sandy soils of various genetic types have developed within the study area. These are black boggy soils, alluvial soils found in the valleys as well as peat soils and muck mineral soils deposited at the bottom of the valley landforms within the moraine plateaus and in marshy depressions [13].

\section{METHODS}

Field investigations were carried out in fallow lands of the Podlaski Przełom Bugu mesoregion over the period 2001-2004. All fallow lands located within the boundaries of this mesoregion were surveyed. 400 relevés were made following the Braun-Blanquet method [14]. The investigations were carried out in 77 villages belonging to 20 municipalities. The location of these villages within the study area is shown in Fig. 1. Floristic inventories were made in the other fallow fields. The time passed from the abandonment of cultivation was determined based on interviews with the residents of the study area and on the basis of the authors' own observations. Four fallow age groups were distinguished: 1-2-year, 3-6-year, 7-10-year and more than 10-year fallows. In analysing vascular plants of fallow lands, the following factors were taken into account: the assignment of species to historicalgeographical groups [15-17], the biological type of species and their persistence [18-20] as well as the assignment of species to sociological-ecological groups $[17,21]$. The following indices were calculated for vascular plants of fallow lands of the Podlaski Przełom Bugu mesoregion and for particular age groups:

- apophytization index WApc - the percentage of apophytes in the flora;

- anthropophytization index WAnc - the percentage of anthropophytes in the flora;

- archaeophytization index WArc - the percentage of archaeophytes in the flora;

- kenophytization index WAKnc - the percentage of kenophytes in the flora;

- modernization index WM - the percentage contribution of kenophytes to the group of naturalized anthropophytes;

- fluctuation index WF - the percentage of ergasiophytes [17];

- dominance index C, biodiversity index H' [22].

\section{RESULTS}

442 vascular plant species belonging to 241 genera and 60 families occur in fallow lands of the Podlaski Przełom Bugu mesoregion. A list of species and their detailed analysis were published in the paper of Skrzyczyńska and Stachowicz [23]. Communities with the highest number of species developed in 3-6-year fallows, since there were 355 species belonging to 54 families. 284 species representing 48 botanical families were recorded in the youngest (1-2-year) fallows. Fewer species were found in communities in older 7-10-year fallows (236 species) and in fallows older than 10 years (205 species) (Table 1).

Regardless of fallow age, hemicryptophytes are the dominant biological type (Fig. 2). They have the highest percentage $(53.4 \%)$ among vascular plants of 7-10-year fallows. In the oldest fallows, the percentage contribution of hemicryptophytes is the lowest, while the number of phanerophytes increases and their percentage reaches $12.7 \%$ in this age group.

In one- or two-year fallows, therophytes co-dominate together with hemicryptophytes. The proportion of therophytes in the other fallow age groups gradually decreases. Chamaephytes and geophytes are a small part of vascular plants in all age groups and they account for about $5 \%$. Native species are predominant in all the distinguished age groups of vascular plants. Their percentage increases with increasing fallow age from $70.8 \%$ in 1-2-year fallows to $80.5 \%$ in plant patches on the soils fallowed for the longest period of time (Fig. 3) 


\section{Bugu mesoregion}

An analysis of the origin of native species shows an increase in the role of native species originating from forest and thicket communities with the increasing time of fallowing from $15.8 \%$ in vascular plants of the youngest fallows to $25.4 \%$ in fallows older than 10 years. Another distinct direction of changes is a decrease in the percentage of archeophytes with increasing fallow age from $20.4 \%$ in 1-2-year fallows to $17.6 \%$ in fallows older than 10 years (Fig. 4).

Perennial species dominate in all fallow age groups (Fig. 5). At the same time, with the passage of time without cultivation treatments, the percentage of persistent species increases from $54.9 \%$ in 1-2-year fallows to $68.3 \%$ in the oldest fallows.

An analysis of the assignment of species to sociological-ecological groups depending on fallow age shows an increase in the proportion of forest species from groups $1,2,3$ with the passage of time from the abandonment of cultivation. Segetal species from groups 15 and 16 predominantly retreat. In the case of vascular plants found in 3-6-year fallows, one can notice both the agricultural past of these phytocoenoses and the directions of changes which are shown by the assignment of species to socioecological groups dominant in older fallows (Table 2).
The apophytization indices (WApc) determined for vascular plants according to fallow age groups increase in value with an increasing period of fallowing from $70.8 \%$ in the youngest fallows to $80.5 \%$ in fallows older than 10 years. The higher indices for fallows older than 10 years confirm the apophytization process taking place in these plant communities. The archaeophytization index (WArc) and the fluctuation index (WF) also demonstrate the directions of these changes. The former one is $20.4 \%$ for the youngest fallows and decreases with increasing fallow age down to $13.2 \%$ in fallows older than 10 years. The fluctuation indices also become lower and lower with increasing fallow age (Table 3). The percentage of new arrivals among vascular plants within the study area, as determined by the kenophytization index (WKc), is the highest for 3-6-year fallows. The degree of modernization (WM) of vascular plants in particular age groups ranges from 0.19 in $7-10$-year fallows to 0.30 in the oldest fallows (Table 3).

The most floristically diverse communities developed in 3-6-year fallows, whereas communities in fallows older than 10 years show the lowest values of the diversity indices (Table 4), but the species dominance index has the highest values in these fallows.

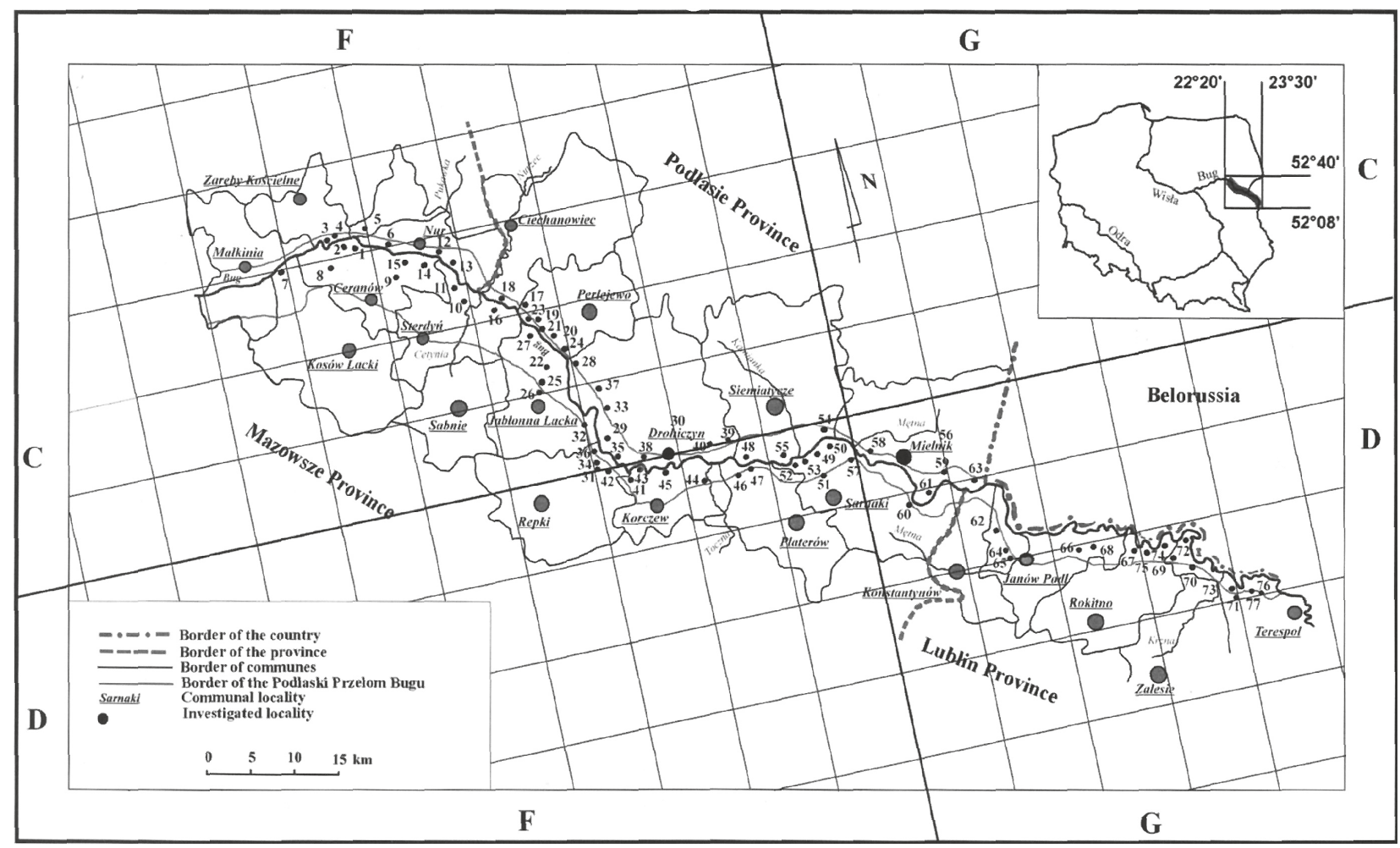

Fig. 1. Investigated area 


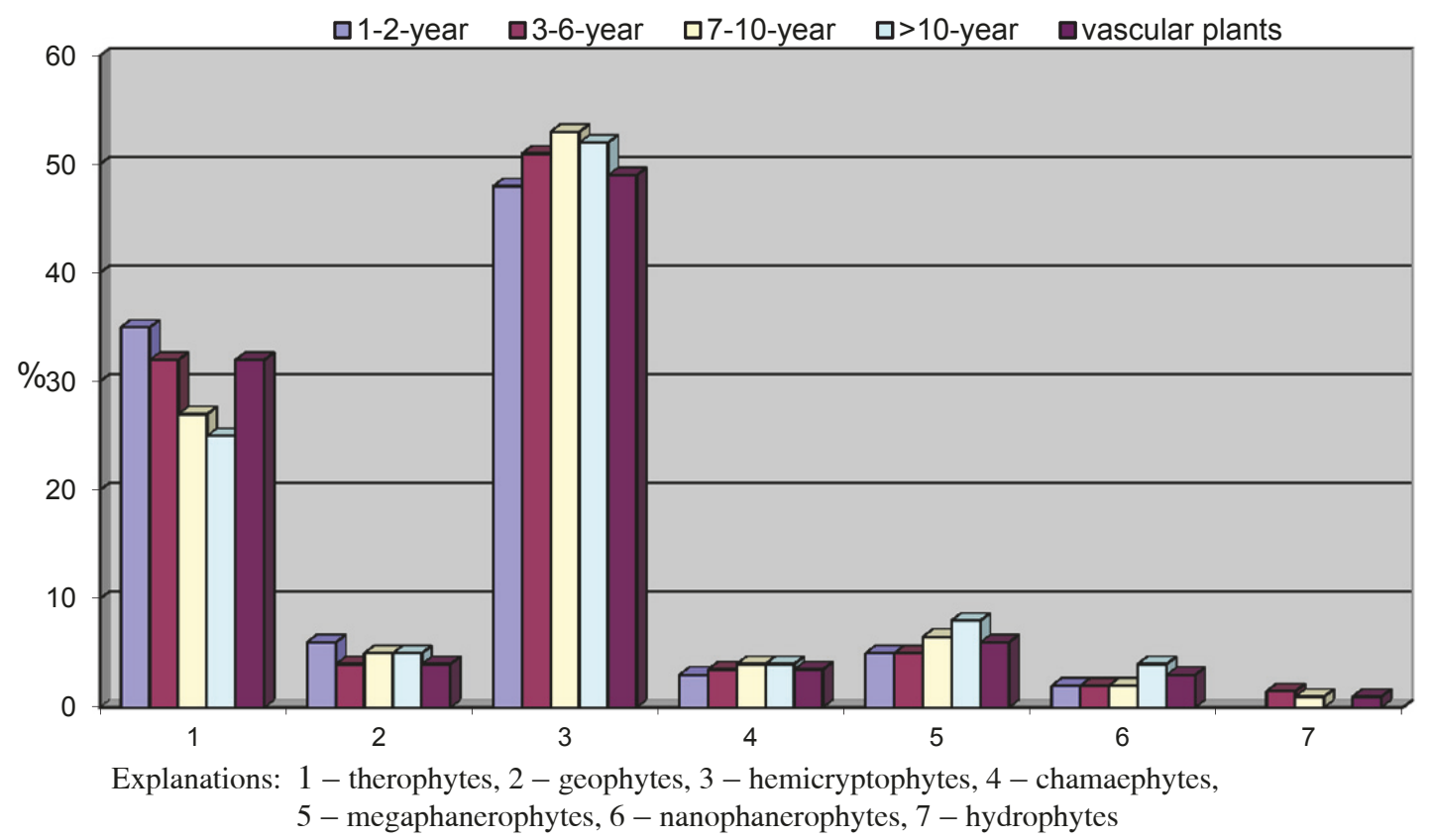

Fig. 2. Biological types of vascular plant species according to age groups of fallows lands in the Podlaski Przełom Bugu mesoregion.

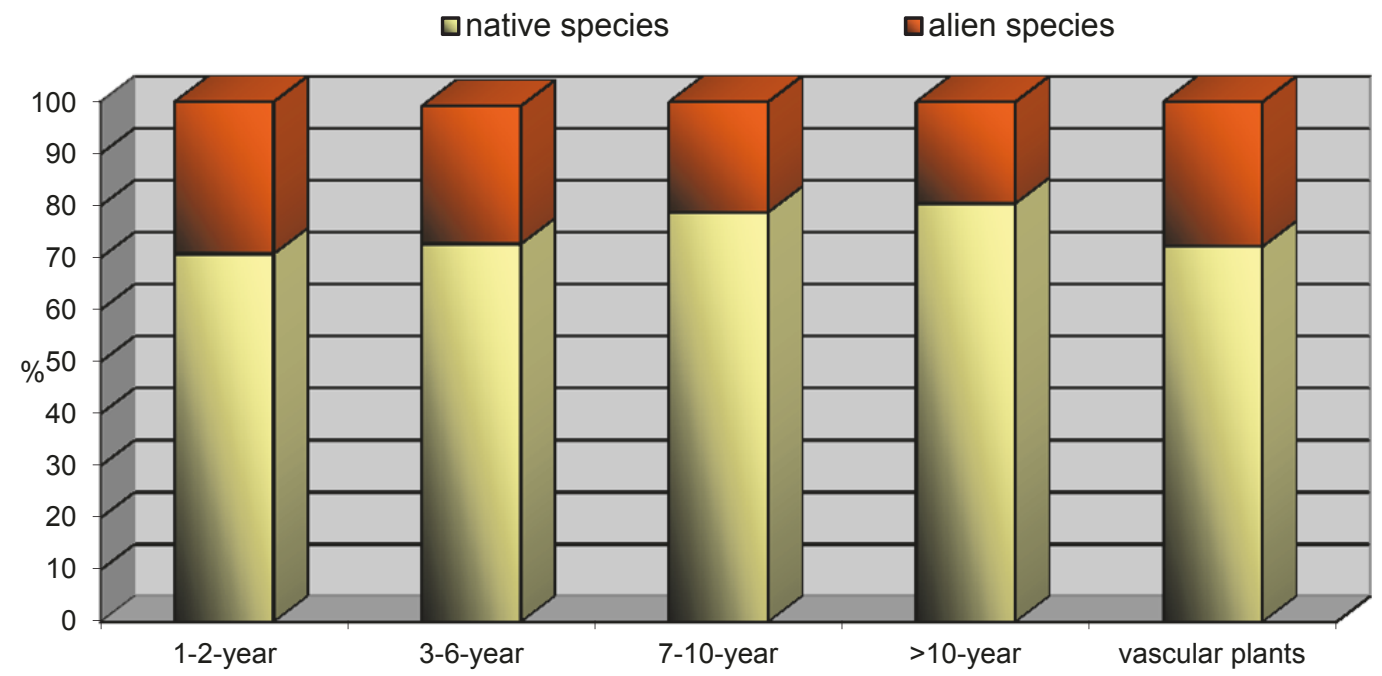

Fig. 3. Percentage of native and alien species in vascular plants of fallows lands in the Podlaski Przełom Bugu mesoregion.

Table 1

Some qualitative characteristics of vascular plants of fallow lands in the Podlaski Przełom Bugu mesoregion

\begin{tabular}{|c|c|c|c|c|}
\hline Fallow age & $\begin{array}{l}\text { Number of } \\
\text { species }\end{array}$ & $\begin{array}{l}\text { Number of } \\
\text { genera }\end{array}$ & $\begin{array}{l}\text { Number of } \\
\text { families }\end{array}$ & $\begin{array}{l}\text { Families represented in greatest numbers } \\
\qquad(20 \text { and more species) }\end{array}$ \\
\hline 1-2-year & 284 & 180 & 48 & $\begin{array}{c}\text { Asteraceae (51), Poaceae (42), Fabaceae (22), } \\
\text { Caryophyllaceae (20) }\end{array}$ \\
\hline 3-6-year & 355 & 208 & 54 & $\begin{array}{c}\text { Asteraceae (62), Poaceae (48), Fabaceae (30), } \\
\text { Scrophulariaceae (24) }\end{array}$ \\
\hline 7-10-year & 236 & 158 & 43 & Asteraceae (45), Poaceae (28), Fabaceae (25) \\
\hline$>10$-year & 205 & 141 & 45 & Asteraceae (35), Poaceae (31) \\
\hline Vascular plants & 442 & 241 & 60 & $\begin{array}{l}\text { Asteraceae (69), Poaceae (57), Fabaceae (38), } \\
\text { Rosaceae (28), Scrophulariaceae (27), Caryophyllaceae (24) }\end{array}$ \\
\hline
\end{tabular}




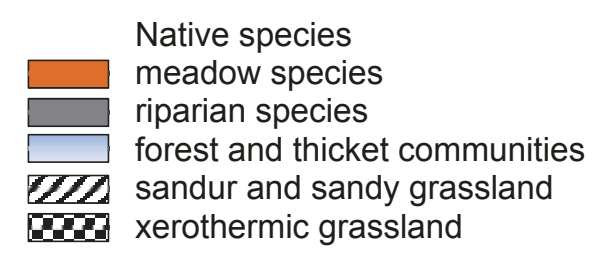

Native species

meadow species

riparian species

forest and thicket communities

xerothermic grassland
Alien species

archeophytes

hemiagrophytes

ergasiophytes

epecophytes

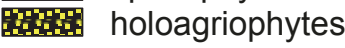

ephemerophytes

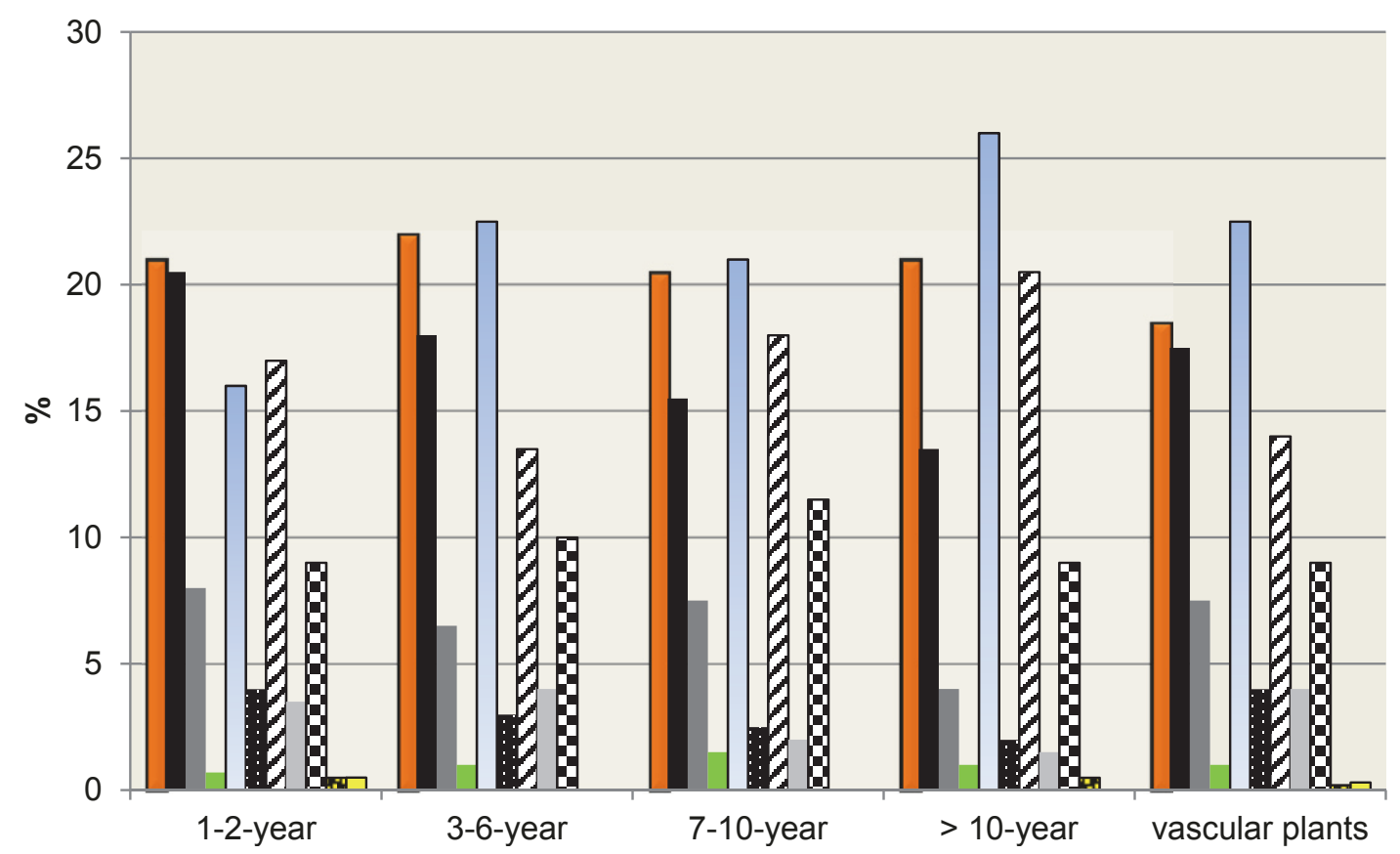

Fig. 4. Origin of vascular plant species according to age groups of fallows lands in the Podlaski Przełom Bugu mesoregion

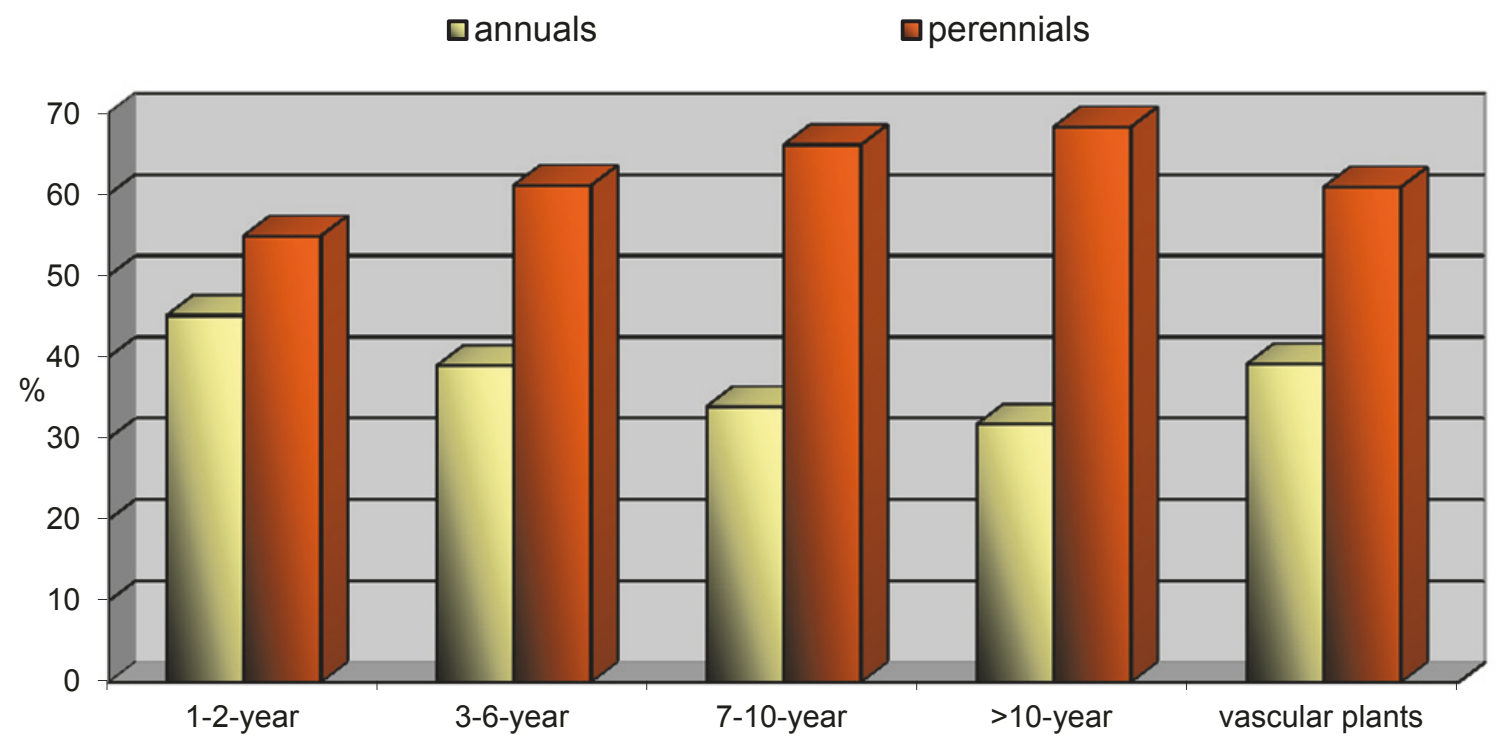

Fig. 5. Persistence of vascular plant species according to age groups of fallows lands in the Podlaski Przełom Bugu mesoregion. 
Table 2

Percentage of sociological-ecological groups in vascular plants according to age groups of fallows lands in the Podlaski Przełom Bugu mesoregion.

\begin{tabular}{|c|c|c|c|c|c|}
\hline \multirow{2}{*}{ Socio-ecological groups } & \multicolumn{5}{|c|}{ Fallow age group } \\
\hline & $\begin{array}{c}\text { 1-2-year } \\
(\%)\end{array}$ & $\begin{array}{c}\text { 3-6-year } \\
(\%)\end{array}$ & $\begin{array}{c}\text { 7-10-year } \\
(\%)\end{array}$ & $\begin{array}{l}>10 \text {-year } \\
(\%)\end{array}$ & $\begin{array}{l}\text { for vascular plants } \\
\qquad \%)\end{array}$ \\
\hline 1 & 4.6 & 8.0 & 5.7 & 10.7 & 9.3 \\
\hline 2 & 5.6 & 7.6 & 8.9 & 10.2 & 7.0 \\
\hline 3 & 1.1 & 2.2 & 3.1 & 2.0 & 2.3 \\
\hline Total & 11.3 & 17.8 & 17.7 & 22.9 & 18.6 \\
\hline 4 & 7.0 & 7.9 & 9.7 & 7.8 & 7.2 \\
\hline 5 & 13.0 & 9.0 & 14.0 & 14.6 & 10.2 \\
\hline Total & 20.0 & 16.9 & 23.7 & 22.4 & 17.4 \\
\hline 6 & 0.7 & 1.7 & 1.3 & 0.5 & 1.8 \\
\hline 7 & 1.4 & 1.7 & 2.5 & 0.5 & 2.3 \\
\hline 8 & 4.2 & 5.6 & 4.7 & 2.9 & 6.3 \\
\hline 9 & 12.0 & 12.7 & 12.3 & 15.6 & 10.6 \\
\hline Total & 16.2 & 18.3 & 17.0 & 18.5 & 16.9 \\
\hline 10 & 6.7 & 5.3 & 6.4 & 6.3 & 4.5 \\
\hline 11 & 3.9 & 2.0 & 1.7 & 1.0 & 2.9 \\
\hline 12 & 3.9 & 3.4 & 3.8 & 3.4 & 3.2 \\
\hline 13 & 9.9 & 7.9 & 8.9 & 7.8 & 8.1 \\
\hline 14 & 1.4 & 3.4 & 1.7 & 1.0 & 3.6 \\
\hline 15 & 10.5 & 8.7 & 6.4 & 5.8 & 7.7 \\
\hline 16 & 9.9 & 9.3 & 6.8 & 7.3 & 8.1 \\
\hline Total & 20.4 & 18.0 & 13.2 & 13.1 & 15.8 \\
\hline $\begin{array}{l}\text { cies of unknown affiliation with } \\
\text { ard to socio-ecological groups }\end{array}$ & 4.2 & 3.4 & 2.5 & 2.4 & 4.7 \\
\hline
\end{tabular}

Deciduous forests and shrub communities

1. Coniferous forests, mixed coniferous forests and their replacement communities

2. Nitrophilous thicket and fringe communities

3. Xerothermic grasslands and fringe communities

4. Psammophilous grasslands

5. Alder carrs and peatlands

6. Aquatic and reed communities as well as riparian forest and thicket communities

7. Moist meadows

8. Fresh and moderately moist meadows

9. Nitrophilous floodplain grasslands and communities subjected to treading

10. Therophytic communities

11. Mesophilic tall-perennial communities

12. Persistent thermophilous ruderal communities

13. Pioneer ruderal communities

14. Weed communities of root crops

15. Weed communities of cereal crops 
Table 3

Synanthropization index for vascular plants according to age groups of fallows lands as well as for segetal habitats and marginal habitats in the Podlaski Przełom Bugu mesoregion.

\begin{tabular}{ccccccc}
\hline & Segetal habitats* & 1-2-year fallows & 3-6-year fallows & 7 -10-year fallows & >10-year fallows & marginal habitats** \\
\hline Wapc & $65.6 \%$ & $70.8 \%$ & $72.7 \%$ & $78.8 \%$ & $80.5 \%$ & $84.6 \%$ \\
Wanc & $34.4 \%$ & $29.2 \%$ & $27.3 \%$ & $21.2 \%$ & $19.5 \%$ & $15.0 \%$ \\
WArc & $24.1 \%$ & $20.4 \%$ & $18.6 \%$ & $15.7 \%$ & $13.2 \%$ & $9.0 \%$ \\
WKc & $4.3 \%$ & $4.9 \%$ & $5.4 \%$ & $3.0 \%$ & $3.9 \%$ & $4.1 \%$ \\
WM & $15.1 \%$ & $19.7 \%$ & $22.4 \%$ & $15.9 \%$ & $22.9 \%$ & $31.9 \%$ \\
WF & $6.0 \%$ & $3.9 \%$ & $3.4 \%$ & $2.5 \%$ & $2.4 \%$ & $2.3 \%$ \\
M & 0.18 & 0.24 & 0.29 & 0.19 & 0.30 & 0.44 \\
\hline
\end{tabular}

* [23]

$* *[24]$

Table 4

Mean values of the biodiversity index $\left(\mathrm{H}^{\prime}\right)$ and of the species dominance index $(\mathrm{C})$ in communities of fallows lands in the Podlaski Przełom Bugu mesoregion.

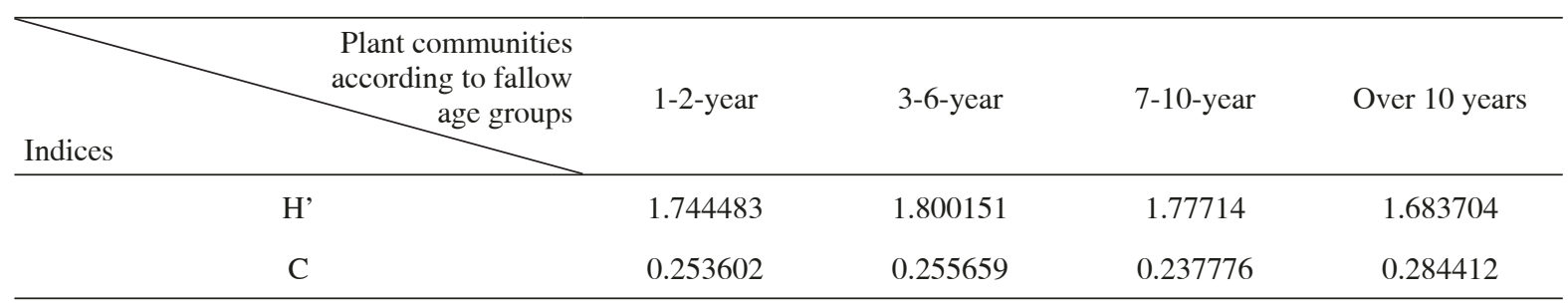

\section{DISCUSSION}

Fallow lands of the Podlaski Przełom Bugu mesoregion are characterized by a richness of vascular plants which number 442 species belonging to 241 genera and 60 families. A lower number of species (348) is found in agrophytocenoses of this area [24] as well as in segetal communities of the neighbouring regions of this mesoregion, among others, 361 species in northeastern Poland [25] and 320 species in the Siedlce Upland [26]. The studied fallows lands are poorer in species than the vascular flora of marginal habitats of the Podlaski Przełom Bugu mesoregion which comprises 571 taxa [27]. The marginal habitats compared are more varied in trophic terms and in terms of humidity as well as they include different types of communities. During the initial stage of fallowing (1-2-year fallows) when there was no crop plant cultivated, typical segetal weeds would take control of fallow fields. In the biological spectrum of vascular plants, hemicryptophytes (more than 48\%) and therophytes (more than $35 \%$ ) are shown to have the highest percentage. This is confirmed, among others, by the studies of authors such as Hochół et al. [28], PodstawkaChmielewska et al. [29,30], Rola [31] as well as Rola and Rola [32]. From the third year of fallowing, there is a decline in the number of therophytes, whereas the number of hemicryptophytes increases. They have the highest proportion in 7-10-year fallows. In the oldest fallows, the percentage contribution of hemicryptophytes is lower, but the proportion of phanerophytes increases. Similar trends in changes with a longer period of fallowing are reported, among others, by Podstawka-Chmielewska et al. [30] and $\mathrm{H}$ o c h ó $ł$ et al. [28]. A continually increasing proportion of perennial species in fallow fields was recorded with the passage of time from the abandonment of cultivation. Their percentage in the youngest fallows was $54.9 \%$, whereas in the oldest ones it was $68.3 \%$. The papers of $\mathrm{E} \mathrm{abza}$ et al. [33] and Now i cki et al. [34], inter alia, confirm similar changes. Interesting results of the study were obtained with respect to the origin of species of vascular plants analysed in fallows of different age within the Podlaski Przełom Bugu mesoregion. Regardless of fallow age, native species dominate and their percentage increases with increasing fallow age. Species originating from forest and thicket communities are predominant among native species. This is corroborated by the studies of Faliński [35] and M a z u r - R y l sk a et al. [36]. The synanthropization 
indices are a measure of changes taking place in vascular plants of fallows lands. As the period of fallowing increases from 1-2 years to more than 10 lat years, the apophytization indices (WApc) rises by about $10 \%$. The anthropophytization indices (WAnc) show a reverse trend. Kuty na and Mal in ow ska [37] obtained similar results in their study. A comparison of these indices with the indices obtained on the basis of the studies of other types of habitats in the Podlaski Przełom Bugu mesoregion $[38,39]$ shows that vascular plants of fallow lands have an intermediate character between segetal flora and marginal habitats due to the degree of synanthropization. The degree of modernization (WM) of vascular plants of various age groups does not exceed the extreme values determined for segetal habitats and marginal habitats [24,38]. In terms of biodiversity, the richest communities are found in 3-6-year fallows, while a longer time of fallowing results in species impoverishment of plant cover of a fallow field [30].

\section{CONCLUSIONS}

1. Vascular plants of the Podlaski Przełomu Bugu mesoregion include 442 species. Their number is the highest in 3-6-year fallows (355 species), while with increasing fallow age it decreases to 205 species in fallows older than 10 years.

2. Regardless of fallow age, hemicryptophytes are the dominant biological type and they have the highest percentage in vascular plants in 7-10-year fallows.

3. In vascular plants of all age groups, native species dominate; their proportion increases with increasing fallow age and at the same time the percentage of alien species decreases.

4. With increasing fallow age, the proportion of forest species belonging to deciduous forests and shrub communities, mixed coniferous forests and nitrophilous thicket and fringe communities increases, while the percentage of segetal species decreases.

5. The synanthropization indices show that with the passage of time from the abandonment of cultivation the species composition of vascular plants in fallow lands which make up segetal communities evolves towards less synanthropic communities.

6. Vascular plants of 3-6-year fallows are characterized by the highest diversity index, whereas species dominance is the highest in the oldest fallows.

\section{Acknowledgements}

Research supported by the Ministry of Science and Higher Education of Poland as part of the statutory activities of the Department of Agricultural Ecology, Siedlce University of Natural Sciences and Humanities.

\section{Authors' contributions}

The following declarations about authors' contributions to the research have been made: concept of the study: JS; field work: JS, PS, ZR, TS; data analyses: JS, PS, ZR, TS; writing of the manuscript: JS, PS, ZR, TS.

\section{REFERENCES}

1. Tryjanowski P, Hartel T, Báldi A, Szymański P, Tobolka M, Herzon I, et al. Conservation of farmland birds faces different challenges in Western and Central Eastern Europe. Acta Ornithol. 2011; 46(1): 1-12. http://dx.doi.org/10.3161/000164511X589857

2. Tryjanowski P, Dajdok Z, Kujawa K, Kałuski T, Mrówczyń ski M. Zagrożenia różnorodności biologicznej w krajobrazie rolniczym: czy badania wykonywane w Europie Zachodniej pozwalają na poprawną diagnozę w Polsce? [Threats to biodiversity in farmland: are results from Western Europe good solutions for Poland?]. Pol J Agron. 2011; 7 : 113-119.

3. Storkey J, Meyer S, Still KS, Leuschner C. The impact of agricultural intensification and land-use change on the European arable flora. Proc R Soc B. 2011; 279(1732): 1421-1429. http://dx.doi.org/10.1098/ rspb.2011.1686

4. Skrzyczyńska J, Stachowicz P. Zbiorowiska roślinne odłogów Podlaskiego Przełomu Bugu [Plant communities on fallow lands of the Podlaski Przełom Bugu mesoregion]. Acta Bot Warm Masuriae. 2007; 4: 187-203.

5. Marks M, Nowicki J. Aktualne problemy gospodarowania ziemią rolniczą w Polsce. Cz. I. Przyczyny odłogowania gruntów i możliwości ich rolniczego wykorzystania [ Current problems of agricultural land management in Poland. Pt. 1. Causes for keeping land fallow and possibilities of agricultural development of such land]. Fragm Agron. 2002; 1: 58-67.

6. Nentwig W. Die nützlingsfördrnde Wirkung von Unkräutern in angesäten Unkreustreifen Z. PflKrankh. PflSchutz, Sonderh. 1992; 13: 33-40.

7. Tołałaj Z, Węgorek T. Zagospodarowanie odłogów i nieużytków w procesie ustalania granicy rolno-leśnej na przykładzie wybranych gmin województwa przemyskiego [Management of fallow land and wasteland in the process of determination of the agricultural-forest boundary on the example of some municipalities of Przemyśl Voivodeship]. Fragm Agron. 1998; 5(98): 81-96.

8. Kondracki J. Geografia fizyczna Polski. Warsaw: Polish Scientific Publishers PWN; 2000.

9. Galon R. Geografia Polski II. Warsaw: Polish Scientific Publishers PWN; 1972.

10. Dylik A. Geografia Polski. Krainy Geograficzne. Warsaw: Państwowe Zakłady Wydawnictw Szkolnych; 1973.

11. Woś A. Typy pogody. Regiony klimatyczne [weather types. Climic regions]. Warsaw: Instytut Geografii i Przestrzennego Zagospodarowania PAN. 1994; ark. 31.8. 
12. Gu miński R. Próba wydzielenia dzielnic rolniczo-klimatycznych w Polsce. Pr Stud Geogr. 1998; 22: 69-117.

13. Wite $\mathrm{k} \mathrm{T}$, editor. Waloryzacja rolniczej przestrzeni produkcyjnej Polski według gmin. IUNG Puławy: 1981.

14. Pawłowski B. Skład i budowa zbiorowisk roślinnych oraz metody ich badania. In: Szafer W, Zarzycki K, editors. Szata roślinna Polski. Warsaw: Polish Scientific Publishers PWN. 1972; 1: 237-268.

15. Kornaś J. Geograficzno-historyczna klasyfikacja roślin synantropijnych. Mat Zakł Fitosoc Stos UM. 1968; 25: 32-42.

16. Zając EU, Zając A. Lista archeofitów występujących w Polsce [The list of archeophytes occurring in Poland]. Zesz Nauk UJ Pr Bot. 1975; 395(3): 7-16.

17. Jackowiak B. Antropogeniczne przemiany flory roślin naczyniowych Poznania. Poznań: Wyd Nauk UAM; 1990.

18. Chmiel J. Flora roślin naczyniowych wschodniej części Pojezierza Gnieźnieńskiego i jej antropogeniczne przekształcenia w wieku XIX i XX. Pr Zakładu Taksonomii Roślin UAM. 1993; 1: 1-201.

19. Chmiel J. Flora roślin naczyniowych wschodniej części Pojezierza Gnieźnieńskiego i jej antropogeniczne przekształcenia w wieku XIX i XX. Pr Zakładu Taksonomii Roślin UAM. 1993; 2: 1-212.

20. Rutkowski L. Klucz do oznaczania roślin naczyniowych Polski Niżowej. Warsaw: Polish Scientific Publishers PWN; 1998.

21. Matuszkiewicz W. Przewodnik do oznaczania zbiorowisk roślinnych Polski. Warsaw: Polish Scientific Publishers PWN; 2001.

22. Zanin G, Mosca G, Catizone P. A profile of the potential flora in maize fields of the Po valley. Weed Res. 1992; 32(5): 407-418. http://dx.doi.org/10. 1111/j.1365-3180.1992.tb01902.x

23. Skrzyczyńska J, Stachowicz P. Flora of fallow lands of the Podlaski Przełom Bugu mesoregion. Acta Agrobot. 2007;60(1):175. http://dx.doi.org/10.5586/aa.2007.021

24. Skrzyczyńska J, Rzy mowska Z. Flora segetalna Podlaskiego Przelomu Bugu [Segetal flora of the Podlaski Przełom Bugu mesoregion]. Acta Agrobot. 2001; 54(1): $115-135$.

25. Korniak T. Flora segetalna północno-wschodniej Polski. Jej przestrzenne zróżnicowanie i współczesne przemiany [Segetal flora of north-eastern Poland, its spatial variation and modern changes]. Acta Acad Agric Tech Olst Agric. 1992; 53(supp A): 5-76.

26. Sk r z y c z y ń s k a J. Studia nad florą i zbiorowiskami segetalnymi Wysoczyzny Siedleckiej. Siedlce: WSR-P; 1994.

27. M a r c in iu k P. Szata roślinna śródpolnych siedlisk Podlaskiego Przełomu Bugu. Cracow: W. Szafer Institute of Botany, Polish Academy of Sciences; 2009.

28. Hochół T, Łabza T, Stupnicka-Rodzynkiewicz E. Zachwaszczenie wieloletnich odłogów w porównaniu do stanu na polach uprawnych [Weed infestation of long-term fallows, as compared with the condition in fields]. Fragm Agron. 1998; 5(98): 115-124.

29. Podstawka-Chmielewska E, Pałys E, Kurus J. Zmiany fitocenoz w czasie wieloletniego odłogowania gruntu na rędzinie [The phytocenosis changes during multiyear arable land lying fallow on rendzina]. Ann UMCS Sec E. 2004; 59(4): 1807-1814.

30. Podstawka-Chmielewska E, Pałys E, Kurus J. Sukcesja roślinności w czasie 10-letniego odłogowania gruntów porolnych na glebie lekkiej [Vegetation succession during 10-year fallowing of abandoned farmland on light soil]. Acta Bot Warm Masuriae. 2007; 4: 23-34.

31. Rola J. Ekologiczno-gospodarcze skutki ugorów i odłogów w Polsce [Ecological and economic consequences of set-aside and fallow land in Poland]. Zesz Probl Post Nauk Rol. 1995; 418: 37-43.

32. Rola J, Rola H. Stan zachwaszczenia ugorów i odłogów na wybranych kompleksach glebowych. In: Mat. XVI Kraj. Konf. „Zmiany w zachwaszczeniu pól wywołane trudna sytuacją ekonomiczną rolnictwa. Szczecin: Akademia Rolnicza w Szczecinie; 1995. p. 6-14.

33. Łabza T, Hochół T, Stupnicka-Rodzynkiewicz E, Jaros J. Zachwaszczenie odłogów i sąsiadujących pól z uprawami zbóż na przykładzie wybranych siedlisk. Cz.II. Pochodzenie i formy życiowe roślin odłogów i pól uprawnych [Weed infestation of fallow fields and adjacent fields with cereal crops on the example of selected habitats. Part I. The origin and life forms of plants of fallow and cultivated fields]. Fragm Agron. 1997; 3: 261-266.

34. Nowicki J, Marks M, Nowicki M, Waniec M. Zachwaszczenie upraw polowych i gleby po zagospodarowaniu kilkuletniego odłogu. Cz. I. Zachwaszczenie zasiewu na tle fitocenozy odłogów. Acta Bot Warm Masuriae. 2007; 4: 401-410.

35. Faliński J. Sukcesja roślinności na nieużytkach porolnych jako przejaw dynamiki ekosystemu wyzwolonego spod długotrwałej presji antropogenicznej [Vegetation succession on abandoned farmland as a dynamics manifestation of ecosystem liberal of long continuance anthropopression]. Wiad Bot. 1986; 30(1): 25-50.

36. Mazur-Rylska A, Ziaja M, Wnuk Z. Zmiany florystyczne na powierzchniach odłogowanych na przykładzie gminy Głogów Młp. i Rzeszów-Zalesie [Floristic changes in fallow lands on the example of the municipalities of Głogów Młp. and Rzeszów-Zalesie]. Acta Bot Warm Masuriae. 2007; 4: 225-237.

37. Kutyna I, Mali nowska K. Struktura geograficzno-historyczna flory zbiorowisk upraw zbóż ozimych i kilkuletnich odłogów [Geographical and historical structure of the flora communities of winter crops cultivation and of a dozen year old fallows]. Folia Pomer Univ Technol Stein Agric Aliment Pisc Zootech. 2011; 283(17): 31-40.

38. Marciniuk P. Szata roślinna śródpolnych siedlisk Podlaskiego Przełomu Bugu. Siedlce: Academy of Podlasie Press; 2002.

39. Rzy mowska Z. Zbiorowiska roślinne pól uprawnych Podlaskiego Przełomu Bugu [Plant communities of cultivated fields of the Podlaski Przełom Bugu mesoregion]. Msc. rozpr. dokt. Zakład Ekologii Rolniczej, WSR-P w Siedlcach. 1999; pp. $127+78$. 


\section{Zróżnicowanie florystyczne}

zbiorowisk odłogów Podlaskiego Przełomu Bugu w zależności od czasu wyłączenia pól z uprawy.

\section{Streszczenie}

Badania odłogów Podlaskiego Przełomu Bugu przeprowadzono w latach 2001-2004 w 77 miejscowościach należących do 20 gmin położonych w dolinie Bugu na odcinku rzeki od Terespola do Małkini Górnej. Celem badań była inwentaryzacja roślin naczyniowych terenów odłogowanych i ich wieloaspektowa analiza. Określono zmiany ilościowe i jakościowe zachodzące w roślinności odłogów z upływem czasu od zaprzestania celowych zabiegów uprawowych. Zbadano płaty roślinne odłogów 1-2 letnich, 3-6 letnich, 7-10 letnich i powyżej 10 letnich. Rośliny naczyniowe odłogów terenu badań liczą 442 gatunki. Najbogatsze w gatunki były odłogi 3-6 letnie (355 gatunków). Wraz z wiekiem odłogów liczebność gatunków malała do 205 gatunków na odłogach powyżej 10-letnich. W zbiorowiskach odłogów dominowały hemikryptofity. $\mathrm{Na}$ najmłodszych odłogach współdominującym typem biologicznym były terofity. Chamefity i geofity wszystkich grup wiekowych odłogów stanowiły około $5 \%$. Wśród roślin naczyniowych odłogów dominowały gatunki rodzime, których udział wzrastał z wiekiem odłogów, jednocześnie zmniejszał się udział archeofitów. Wraz z wiekiem odłogów wzrasta także udział gatunków charakterystycznych dla zbiorowisk leśnych, równocześnie malał udział gatunków segetalnych. Wraz z upływem czasu od zaprzestania uprawy widoczne jest ewoluowanie szaty roślinnej odłogów od zbiorowisk segetalnych w kierunku zbiorowisk mniej zsynantropizowanych.

Handling Editor: Elżbieta Weryszko-Chmielewska

This is an Open Access digital version of the article distributed under the terms of the Creative Commons Attribution 3.0 License (creativecommons.org/licenses/by/3.0/), which permits redistribution, commercial and non-commercial, provided that the article is properly cited. 